\title{
A Bacterial Disease of Potato Leaves.
}

\author{
BY \\ ELIZABETH DALE \\ (Sometime Pfeiffer Student, Girton College, Cambridge). \\ With Plates XV and XVI.
}

Contents.

I. Symptoms and Mode of Occurrence.
2. Histological Characters of the affected Potato Plants
3. The Parasitic Organism and its Culture
4. Infection Experiments

I. Symptoms and Mode of Occurrence.

$\mathrm{T}$ the course of some experiments made in 1909 with potato plants grown from tubers affected with 'blindness', i. e. in which the 'eyes' had been more or less completely destroyed by Verticillium albo-atrum, certain pathological phenomena were observed which were at first thought to be due to the disease then under investigation, namely 'blindness'.'

Further observations, however, showed that two distinct diseases were in question. One of these, 'blindness', affects the tubers and underground stems exclusively, while the other, which is due to Bacteria, is almost as exclusively confined to the leaves.

The plants in which the latter disease was first observed were three, grown from tubers affected with 'blindness', and containing the mycelium of Verticillium albo-atrum. Two of these tubers had been kept in damp air for nine days, and had begun to form new and apparently healthy ' eyes'. The plants grown from these tubers were labelled respectively ' $\mathrm{I} a$ ' and ' $I$ ' '. A third tuber, which was dry and resting, had only traces of ' eyes'. It was marked ' 3 '. Each tuber was planted in a flower-pot on

${ }^{1}$ Dale : On the Cause of 'Blindness' in Potato Tubers. Annals of Botany, vol. xxvi, No. ci, I9I2, p. I 29.

Annals of Botany, Vol. XXVI. No. CI. January, 1912.] 
May I2, I909. Besides these tubers, cuttings of shoots from apparently healthy tubers were planted. It is noteworthy that the plants grown from these cuttings were not attacked by the disease, which appeared on the plants grown from the 'blind ' tubers.

Each of the three tubers produced shoots which at first were apparently healthy. But by June Io, i. e. in about a month after the tubers had been planted, the shoot of 'plant 3 ' began to show symptoms of disease. The leaves were somewhat wrinkled, becoming slightly yellow and covered with small brownish spots.

One of the leaves was cut. In the fresh leaf the brown spots were seen to be due to isolated cells, or rows of cells, densely filled with granules showing active movement. These cells are to be distinguished from other cells containing colourless crystalline granules.

In the former cells the granules are stained by dyes, while in the latter the granules are not stained and are refractive, so that if the granules are examined in reflected light they appear white, whereas the stainable granules are black, though both usually exhibit active movements in sections of fresh leaves. The stainable 'granules' were found later to be Bacteria.

By June I 5 'plant 3 ' showed clear symptoms of 'leaf-curl'. The leaves were rolling up at the edges and were going yellow in large patches, and the veins of the leaves were turning brown from the edge towards the centre of the leaves. The leaves gradually became more yellow and dropped off, from below upwards. Sections of the leaves with brown veins showed that, in addition to the isolated cells with stainable granular contents, referred to above, the vascular tissues were turning a bright brown. At this stage were first observed, in the larger veins, certain colourless tubes, with highly refrac. tive walls, of very irregular size and thickness. These tubes were obviously not fungal, and their significance and nature were not at first apparent.

In ' plants I $a$ and $1 b$ ' there were similar signs of disease, and sections showed both cells with granules and also large numbers of tubes.

By June 2i ' plant I $a$ ' (which had been covered with a bell-glass for about a week) was almost dead. It had five large shoots (one had been cut off and fixed earlier) and three small shoots. Three out of the five had no green leaves; the stems were yellow and covered with elongated brown patches. The leaves were brown, shrivelled, and very slightly attached to the stem. The other two shoots had green stems with a few yellowish green leaves at the top. The three short shoots had yellowish green or brown leaves.

'Plant I $b$ ', which had not been covered, had green leaves on all its three shoots, but the veins were going a purple-brown colour on the under sides of the leaves, and the leaves were shrivelling from the tips downwards, while some were dropping off. 'Plant 3 ' was almost as badly affected as 'plant I $a$ '. 
A leaf of 'plant I $a$ ' was cut to see if any change had taken place in the tubes in the veins. They were still quite distinct, only slightly branched, and they nearly all ended in cells filled with stainable granules.

Plants with this disease almost invariably show marked symptoms of 'leaf-curl' and 'leaf-roll', but 'leaf-curl' may occur in plants which have not, as far as could be determined, yet been attacked by the organism causing the disease. A plant showing marked 'leaf-curl', but no traces of browning or wilting, was cut down, and each internode and its adjoining leaf put into separate bottles in absolute alcohol. A microscopic examination of these leaves and stems showed no traces of tubes, granules, Fungi, or any other sign of disease beyond the actual 'curl'. On the other hand, the brown veins and tubes may occur in leaves which are flat and remain so.

In the spring of I9IO, and again in I9II, the disease appeared spontaneously in plants grown in pots in a cool greenhouse, some from the original 'blind' stock and some from tubers which were apparently healthy. Attempts were also made to grow seedlings for infection in sterile soil, but, though the seedlings readily germinated, further growth would not take place in sterile soil, so that plants grown in ordinary soil had to be used. The tubes obtained were in all cases similar. As before, some of the plants, but not all, showed symptoms of 'curl'.

\section{Histological Characters of the affected Potato Plants.}

Leaves from the three plants described above were fixed in chromeacetic acid. Various stains were used, but by far the best method was found to be double staining with diamond fuchsin and light green. The sections were placed for about two minutes in fuchsin, washed in water, then very rapidly stained with light green by pouring the stain on the slide and washing it off again at once with absolute alcohol, which must not be left on the slide more than a minute before the sections are cleared in oil of cloves. Hand sections, however, require a longer time in absolute alcohol after the light green, in order to differentiate the stains and wash out the excess of fuchsin.

In the sections thus treated the tubes and Bacteria were stained bright red, while all the tissues of the host plant, with the exception of those which were lignified and of the nuclei, became green. It is therefore quite easy to trace the distribution of the parasite in the host plant by means of the coloration.

The tubes also stained well with alkaline methylene blue. In some cases the sections were treated with alcoholic caustic potash, before staining, to swell the tubes.

In stained microtome sections the tubes are to be found in all parts of the leaf, though they are largest and most numerous in the large veins. In 
sections of fresh leaves the tubes are easily overlooked in the mesophyll on account of the presence of chlorophyll. They are also inconspicuous in unstained hardened material because of their small size compared with those in the veins.

It was at first uncertain whether the tubes were formed inside the leaf and grew outwards, or whether they originated at the periphery. Various considerations led to the conclusion that the latter is the case.

In early stages of the disease, when there are few or no cells containing Bacteria, the tubes are seen to occur at the periphery and to extend inwards for varying distances. They were never observed in the deeper tissues only.

In many cases the tubes are narrow at the surface of the leaf and widen irregularly towards the centre, but not infrequently they show a large swelling at the surface. In the case of branching tubes the branching usually occurs in the neighbourhood of the vascular tissues and not near the surface. It is much more probable that the tubes branch than that they anastomose, though this does seem to occur occasionally.

It may therefore be concluded that the tubes begin at the surface and pass inwards. How is the entrance effected? In no single case, amongst the hundreds of sections examined, was a tube seen to enter the leaf through a stoma. This point has been studied carefully both in surface view and in transverse sections. In every case the tube pierces the epidermis, almost always where two adjacent cells are in contact. This may be seen by looking at any of the diagrams representing tubes at the surface, either in surface view or in section.

A horizontal section of a vein is shown in Pl. XV, Fig. I, where the epidermal cells are seen in surface view. Two stomata are represented surrounded by epidermal cells, on the walls of which, in almost every case where two adjacent cells are in contact, are numerous tubes in early stages of formation. The unaltered tissues of the host are stained green, the parts attacked by the disease take up the red colour.

Figs. 2 and 3 show two later stages. In surface views there is usually a deeply staining, approximately circular mass, often with an irregular lumen in the centre. Comparison with a section (Fig. 4) shows that this deep red area is a more or less hemispherical mass at the mouth of the tube (cf. Figs. 2 and 3 with Fig. 4).

In other cases the tube is extremely narrow at the surface (Figs. 5 and 8 , \&c.). Whether narrow or wide, it frequently shows one or more points projecting above the surface (Figs. 4, 5, 10, \&c.).

After piercing the epidermis the tube grows at right angles to the surface along the middle lamella of two adjacent cells. Rarely it seems to cross the centre of a cell. At the point where the tube pierces a wall there is often a swelling (Pl. XV, Fig. 6, and Pl. XVI, Fig. 20). On arriving at an intercellular space the tube crosses the space (Fig. 7), often with a very 
tortuous course, and passes between two cells on the other side. Occasionally tubes branch (Fig. 9) and, more rarely, anastomose (Fig. 8). Sooner or later the tube enters a mesophyll cell (Figs. 8, 9, and I2), in some cases near the epidermis (Fig. 8), or even into an epidermal cell, but more usually into a cell near the vascular tissue (Figs. 8 and 9). Though frequently occurring in the vascular tissues, tubes are scarcely ever seen in the vessels, though often in the phloem. The cells in which the tubes end are filled with Bacteria which usually stain red.

The tubes themselves are very irregular in outline and vary considerably in thickness. Irregular constrictions are common (Pl. XV, Figs. 5, $7 ; \mathrm{Pl}$. XVI, Fig. II), and these are independent of the cell-walls of the host plant, as they are clearly visible in tubes crossing intercellular spaces (Fig. 7). The walls often present a corrugated appearance (Figs. 5 and II). On the other hand, some tubes may be very straight and cylindrical (Figs. 6, 10, and 20). There is usually a lumen which is relatively narrow, though it varies in diameter (Figs. 6 and 7). The two sides of a tube are in many cases by no means parallel (Figs. 7, II, I 3 ).

The growing end of a tube is generally swollen and pointed (Fig. 5). Such swollen ends may be seen in intercellular spaces (Fig. 7) and also in the cells containing Bacteria. In some cases the tubes appear to pass right through the Bacteria-containing cells, or several tubes may end in one cell (Figs. IO, I2).

In the later stages of the disease the tissues of the host become extremely disorganized, especially in the neighbourhood of the veins. In these stages the affected tissues of the host plant, as well as the parasite, take up the fuchsin, so that the tubes cannot be so clearly followed.

It is noteworthy that sections of stems show no tubes or Bacteria, or at most very slight traces. The disease is confined, as far as could be determined, to the leaves. The explanation of this fact seems to be that the cuticle of the stem is too thick for the tubes to penetrate. In this connexion it may also be noted that in pure cultures of the organism grown on sterilized potato there was little or no growth on the 'skin' of the tuber, whereas the cut surface was rapidly covered with a thick mass of Bacteria.

\section{The Parasitic Organism and its Culture.}

The appearance of the tubes and of the granule-containing cells strikingly recalls, in many respects, those occurring in the nodules of leguminous plants, and shown by Miss Dawson ${ }^{1}$ to contain, and to be formed by, organisms resembling Bacteria. Sections of nodules of Pisum sativum, fixed and prepared in the same manner as those of the potato leaves, showed similar reactions towards dyes. Morphologically there is also

1 Dawson: 'Nitragin' and the Nodules of Leguminous Plants. Phil. Trans., Series B., vol. cxcii, I 899 , p. I. 
much resemblance, but the tubes in the potato leaf are the bigger, and in many cases the less branched of the two. The mode of entry in each case is similar, as the infection tubes of leguminous plants penetrate the cellwall of the root-hair, while those of the potato plant pierce the thin cuticle of the leaf. In both cases there is frequently a swelling at the point of entry and a dilatation where the tube pierces the cell-walls of the host. This may be seen by comparing the diagrams of the different tubes (cf. figures in this paper with those in Miss Dawson's).

In both cases the tubes finally pass into cells which are filled with granules that stain like the tubes. It seemed probable, therefore, that in each case a similar organism was concerned. Attempts were accordingly made to isolate an organism from leaves in which tubes and granules had been found by previous microscopical investigation. These attempts were not made until I9I0, as in I909 the nature of the tubes was still undetermined.

Leaves showing marked 'curl' were obtained from plants grown in a greenhouse from small but apparently healthy tubers which were planted on February 3. By March II-i. e., as in the preceding year, after about a month-tubes and stainable granules were found in the leaves. From pieces of these leaves Bacteria were obtained by means of plate cultures of gelatine containing extract of potato tubers. The leaves were remarkably free from Fungi or Bacteria, other than the one obtained, so that pure cultures were easily and quickly made.

It may here be noted that various kinds of Bacteria were obtained from potato tubers, and compared with those from potato leaves, but in no case were they the same in their behaviour on culture media.

In the spring of I9I I, from a badly diseased plant, in which tubes and Bacteria were abundant, three kinds of organisms were obtained. One of these was identical with that isolated in I9I0. Of the other two, one was an organism with a most remarkable habit of growth: on potato tubers it formed large Tremella-like gelatinous masses, a centimetre or more above the surface of the tuber. ${ }^{1}$ These masses were corrugated at the edges, and resembled a gelatinous fungus far more than Bacteria. The culture was not slimy but exceedingly tenacious, so that strong pressure with a cover-slip did not break it up. Microscopic examination showed that the gelatinous mass consisted of roundish, highly refractive Bacteria, embedded in masses of gelatinous substance, and relatively widely separated from one another.

The third form was somewhat like the second, but so feebly growing that the culture of it was soon abandoned.

The original Bacteria obtained from leaves in I9Io grew well on a number of media, but most successfully on pieces of sterilized potato

1 This growth was confined to the cut surfaces of the tuber and never spread to the 'skin' of the potato. 
tuber, at a temperature of $25^{\circ} \mathrm{C}$. Under such conditions the Bacteria form a dirty white film which quickly grows in thickness, but which is almost exclusively confined to the cut surface. The cultures are very slimy and pull out into strings. As they grow, they give off a quantity of gas which raises bubbles on the surface of the cultures. The cultures, when old and becoming dry, sometimes turn a purplish or reddish-brown colour, recalling that of the veins of potato leaves in which this organism is parasitic.

The organism is very dependent on an abundant supply of water, and growth soon ceases, even on potato tuber, when the substratum becomes in the least dry, even though the food supply is by no means exhausted. Pieces of sterile (boiled) potato tuber, with cultures of the organism, were fixed in chrom-acetic acid, cut with a microtome, and stained with diamond fuchsin and light green (Fig. I4). Sections showed that the Bacteria were present in large numbers between the cells, filling up the intercellular spaces, whereas only a few, even in a culture a month old, were seen inside the cells and attached to their contents. The starch was apparently not attacked at all, as the contents of the cells gave a dark purple colour with iodine. These contents were chiefly the starch grains, boiled to a paste in the process of sterilization. The distribution of the Bacteria in the tuber was very clearly shown, as they took the usual bright red stain, while the walls and contents of the cell became a uniform green, with the exception of the starch grains and nuclei. It is noteworthy that the abundant proteid crystals resisted all the processes of sterilization, fixing, washing, and staining. They still retained their crystalline form, and stained red with fuchsin.

The organism was also grown on living potato tuber, which was sterilized as far as possible by cutting pieces from the centre of a sound tuber with a sterilized knife. The pieces of tuber were put in a sterile Petri dish, and sterile distilled water containing the organism was poured over them. A control section was placed in a dish containing sterile distilled water only. In about a week the control piece of tuber was unchanged, and the infected slice was brown and rotten and smelt strongly ammoniacal. Sections of the living material showed Bacteria between the cells, and few or no Bacteria inside the cells, which contained unchanged starch grains, stained red with fuchsin. One of the pieces of rotting tuber was fixed in chrom-acetic acid, cut with a microtome, and then stained with fuchsin and light green. In the parts where rotting was only beginning and the tissues were still firm (Fig. I5), the Bacteria were seen to be abundant between the cells, which were widely separated so that they easily fell apart. Apparently the middle lamella is first attacked and dissolved, and then the cellulose walls, which stain red as in the leaves. In some sections spores were abundant, as well as ordinary Bacteria, in the intercellular spaces. Some of the spores are shown in Fig. 15 , in the angles between the cells. The 
spores stain a deep red; many of the Bacteria stain green, perhaps because the red colour was washed out in the course of preparation of the slide.

In comparing sections of sterilized (boiled) tuber with those of living tuber, it is suggestive that in the former the walls of the host do not stain red in the parts attacked by Bacteria, as they do in the latter. The explanation seems to be that in the living tuber the middle lamella is first attacked and dissolved by the organism, and then the cell-wall itself, whereas in the sterile tuber the isolation of the cells is brought about, before infection, by the process of steaming. Thus the organism finds a path already opened.

On potato extract in gelatine the organism grows well and liquefies the gelatine slowly. In a streak culture it first liquefies the part below the streak, forming a deep channel down which the culture slips into the liquefied medium at the base of the tube, where it proceeds to liquefy the remaining gelatine. The completion of the process takes days or even weeks in a low room-temperature.

On potato extract in agar, especially in an incubator at about $25^{\circ} \mathrm{C}$. (the ordinary temperature of the laboratory in winter being low), the organism grows well. The cultures were slimy, as in gelatine, and pulled out into strings. As this medium dried up rather soon the growth ceased.

On 'Lemco' beef bouillon in gelatine at a somewhat low ordinary temperature (about $13^{\circ}-15^{\circ} \mathrm{C}$.) the organism grew well. The gelatine was slowly liquefied, at first along a groove as in potato gelatine cultures. The liquid part of the culture was turbid and contained flecks of pellicle.

In a stab culture a large circular mass of Bacteria was formed, thick in the centre and thin at the edges. Growth also occurred, but not very abundantly along the line of stab, the separate colonies each appearing as isolated round dots.

In the incubator, at $25^{\circ} \mathrm{C}$., a good growth was obtained in liquid gelatine, the organism falling to the base of the tube as a whitish precipitate. A thin pellicle was formed on the surface. This film broke up and sank when the tube was shaken.

Wood ashes in agar, at $12^{\circ}-15^{\circ} \mathrm{C}$.

Streak culture. There was a considerable growth in all the cultures made.

Stab culture. A fair growth was formed along the line of stab, but there was no special development on the surface. The organism spread along the line of stab in wavy films or cloudy masses, which are very characteristic, and quite different from the isolated colonies formed in Lemco, and in cane-sugar and peptone gelatine. The difference seems to be due to the medium, isolated colonies being formed in gelatine, and wavy, cloudy growths in agar. 
At $25^{\circ} \mathrm{C}$. a fair growth developed on a streak, and a stronger development in a stab culture, as in the cultures at lower temperatures.

Urea in agar. At ordinary temperatures and in the incubator good growths were obtained on both streak and stab. The streak culture forms a broad, straight, and rather wide band. The stab culture formed a film over the surface, and also grew down the medium in a filmy manner as in wood ashes in agar.

On cane-sugar and peptone in gelatine ${ }^{1}$ growth was very abundant. Large bubbles of gas were given off in such numbers as to form a frothy mass on the surface of the solid medium. Bubbles were also given off along the line of stab cultures, in spite of the solidity of the medium. As in other gelatine cultures, the colonies in a stab were clearly distinguishable with a hand lens as isolated round dots. Liquefaction here also was very slow and was not complete for some weeks. There is a distinct formation of acid, during which the neutral litmus becomes first red and then colourless.

On sterile milk. Several tubes, prepared according to the method given by Percival, ${ }^{2}$ were infected with the organism, and one uninfected tube was placed with them as a control. In the incubator, at $25^{\circ} \mathrm{C}$., by the next day the infected milk was going yellow at the top. At about $\mathrm{I} 3^{\circ} \mathrm{C}$. no change was visible. On the second day the infected milk in the incubator was coagulated and the violet colour had disappeared. There was a yellow liquid at the top and an almost pure white coagulum below. The milk in the control tube remained unchanged. At the lower temperature of the room the infected milk was changing colour but was not yet coagulated. After some time the coagulum disappeared.

On beer-wort gelatine there was very little growth, which is somewhat surprising as this organism grows so freely on so many media, and also because most organisms grow well on this particular medium.

Aerobism. A test-tube containing a stab culture of the organism in cane-sugar, peptone, and gelatine was placed in a larger tube containing a mixture of caustic soda and pyrogallin. Growth occurred abundantly, as was shown by the evolution of gás in the culture tube.

A second experiment was made, using the method given by Pethybridge and Murphy. ${ }^{3}$ A streak culture of the organism was made in agar (urea was used in this case) and immediately plugged with melted agar to exclude the air. In this tube also growth was vigorous. The organism can therefore live under anaerobic conditions.

1 This medium was made up as follows: cane-sugar $1.5 \%$; peptone $0.5 \%$; gelatine $10.0 \%$; distilled water 30 c.c. ; neutral litmus.

2 The milk was prepared as follows: Milk was passed through a separator. If not neutral it was rendered so, and a little neutral litmus added, which gave the milk a purple colour. The separated milk was sterilized in plugged tubes. Percival, Agricultural Bacteriology, I9IO.

3 Pethybridge and Murphy: A Bacterial Disease of the Potato Plant in Ireland and the Organism causing it. Proceedings of the Royal Irish Academy, vol. xxix, section B, no. I, 19I I. 
The size and shape of colonies. Plate cultures were made in gelatine and agar. The colonies obtained were round or oval, and in some cases showed pseudopodial-like prolongations, but this may be due to the pressure of the cover-slip on the gelatine. In the colonies the Bacteria are quiescent, but when liberated they are actively motile.

The organism grows well at $25^{\circ} \mathrm{C}$. and also at $35^{\circ} \mathrm{C}$. There is no growth between $35^{\circ}$ and $45^{\circ} \mathrm{C}$, and the thermal death point is about $50^{\circ} \mathrm{C}$.

The cultures on the various media were examined microscopically at different ages, fresh, stained alive with water methylene blue, and in permanent preparations made on cover-slips and stained with various aniline dyes. The organism differed considerably according to different conditions, so much so that doubt was felt as to whether the cultures were the same. But the point was settled by cross cultures from one medium to another, the results being constant.

The organism is much more motile in liquid than on solid media. It is rod shaped, but the rods vary greatly in size, and especially in length, and sometimes grow into filaments which may be as much as $5 \mu$ long. The average size is $3.7 \mu \times \mathrm{I} .23 \mu$, the minimum $2.4 \mu \times 0.8 \mu$, the maximum $5 \mu \times \mathrm{I} \cdot 7 \mu$ 。

In cultures on potato tuber, which are extraordinarily vigorous, rods of all lengths were found, some very small and scarcely motile in the slimy masses of zoogloea, others longer and wider in the more liquid parts of the culture. In this same culture, after only three days' growth in an incubator at $25^{\circ} \mathrm{C}$., there were quantities of ripe spores as well as spores in process of development.

Formation of spores. The spores and spore-bearing individuals are so much larger than the average vegetative bacillus that at first sight they do not seem to belong to the same organism. But similar preparations have been made from different cultures, and in one and the same preparation all stages may be traced from the ordinary small vegetative bacillus to the ripe spore. The development is shown in Fig. 16. The ordinary bacilli are shown at $a^{1}$ and a long filament at $a^{2}$. Larger and somewhat more deeply staining individuals are seen at $b$. Still larger, and in some cases longer, individuals are represented at $c$, where the contents may be seen to be contracting and leaving the wall. In the next stage, $d$, the protoplasm is breaking up into segments, which vary in number according to the length of the spore-bearing rods. At this stage or earlier the rods may break up into smaller pieces. The spore-bearing rods are often seen to be surrounded by a faintly staining halo $(c$ and $d$ ) which shades off gradually, separating the rods more or less widely from one another. This is no doubt the slimy matrix in which the rods are embedded if they are in a zoogloea, as is frequently the case in subaerial cultures. Inside the rods the spores are formed by the rounding off of the protoplasm, which becomes 
surrounded by a thick wall. The contents of the ripe spores show marked apical staining (Fig. I6,e). Most frequently two spores are formed in a short rod, or segment of a rod. In some cases a long rod breaks up into many spores, some of which do not attain to maturity. In the case of a short rod with two spores, only one may develop fully $(g)$.

A portion of zoogloea with the vegetative rods embedded in a gelatinous matrix is seen in Fig. $16, h$.

\section{INFECTION EXPERIMENTS.}

Attempts were next made to infect potato leaves, both of seedlings and of mature plants, with the organisms described above. Some of these experiments were made in I9IO and the others in I9II, some in a greenhouse, others in the open. In both years the climatic conditions were unfavourable for experiments in the field. In I910 the weather was so damp that the plants soon succumbed to Phytophthora. In I9II, on the other hand, the heat and drought were so great that, except early in the year, the Bacteria all dried up before they were able to enter the tissues of the host.

I. In I9I0, owing to an unavoidable interruption in the work, the infections could not be made until August. Cultures of Bacteria from both leaf and tuber were used. The latter gave negative results, however, and they were consequently abandoned.

Bacteria from the same culture tube were used to infect both the seedlings and the mature plants. In some cases the Bacteria were laid on the leaf and left to find their own way in; in other cases a wound was made with a platinum needle which had been first dipped into the culture.

The infections were made on August I3. The seedlings used had been grown in a greenhouse and were infected in situ. By August 29, i. e. in sixteen days, the infected leaves showed symptoms of leaf-curl, and were also turning brown in places. Some of these leaves were fixed in chrom-acetic acid and examined later.

The mature plants, grown from tubers, were some of an unusually late crop which appeared to be healthy, although most of the potatoes in the neighbourhood had been badly attacked by Phytophthora. The infections were also made on August I3. As in the case of the seedlings the organism obtained from tubers did not infect the leaf. The Bacteria were either laid on the leaves, which were wet with rain, or were stabbed into the tissues with a platinum needle. At first the infected plants were covered with bellglasses and shaded with cloths. The glasses were removed after three days, but the cloths were retained as a screen from the sun and also as a possible protection from the attacks of Phytophthora. $=$ By August 29 several infected shoots showed signs of leaf-curl and of browning. These were fixed in methylated spirit. 
In November of the same year (I9I0) some potato and tomato seedlings were infected with Bacteria obtained by carrying on the original cultures from the potato leaf. In these later experiments the Bacteria were all laid on the surface (either upper or lower or both) of the leaf, which had previously been wetted with boiled distilled water. No mechanical injury whatever was done to the tissues of the host by stabbing.

The plants were covered with bell-glasses and placed in a cool greenhouse. The infections were made on November I6. In two days brown spots began to appear on the infected leaves of those plants which had been kept most damp. Some which were drier were at first unaffected until sterile distilled water was put upon the leaves. Both the tomato and potato plants excreted large drops of water round the edges of their leaves, and it was observed that some of these became cloudy with Bacteria. This fact suggests the reason why the leaves begin to wither first at the apex and round the edges. Most probably infection takes place where there is the greatest amount of water, though, as stated above, it is quite independent of the stomata. Several leaves were fixed three days after infection. The infected leaves later became brown in patches and along the veins, and some appeared glassy-looking in patches. By no means all the leaves showed signs of 'curl' even when badly infected.

2. In IgII, infection experiments were begun earlier in the open at the University Farm, in a field of potatoes which was kindly put at my disposal by Professor Biffen.

This year the original organism was used, and also those obtained from the diseased plant cut down and examined in February, I9I I.

The first experiments were made on June 8 , when the weather was already very hot and dry, but there was some rain at the end of the month. With this exception there was hardly any rain at all until the end of the season, and the temperature not infrequently rose to over $90^{\circ} \mathrm{F}$. in the $\operatorname{shade}^{1}\left(35^{\circ} \mathrm{C}\right.$.), and was of course much higher in the sun.

The method used was slightly altered, and was as follows: The lower leaves were cut off to prevent their being confused with those which had been infected. The young upper leaves were wetted with distilled water. In the case of very hairy leaves it was found necessary to rub the water gently on the leaf, especially on the under surface, to ensure its being thoroughly moistened. The Bacteria were laid on the wet leaves and no punctures were made until quite late in the summer, when, owing to the drought, the Bacteria could not enter the host. ${ }^{2}$ Each of the infected shoots was covered with a bag made of thin typing paper, waterproofed with paraffin and petrol, and then sewn up. By this means the plant was pro-

${ }^{1}$ It is important in this connexion to remember that the organism will not grow above $35^{\circ} \mathrm{C}$.

2 The drought would tend to make the epidermal walls of the host thicker and firmer, and therefore more difficult for the Bacteria to pierce. 
tected to some extent from dryness and excessive light. Some leaves were infected on the upper surface only, some on the lower surface only, and others on both sides. Several varieties of potato were infected, including 'White City', 'Up-to-Date', 'British Queen', and 'Maresland Queen'.

The results of these experiments will not be given in detail, partly because later in the season so many gave no results, and also because the plants were attacked by a fungus, apparently Cladosporium. The symptoms of the disease caused by this fungus are externally so like those due to Bacteria that only a microscopic examination shows which is present. Both diseases may occur in the same leaf.

The positive results, though few in number, are indisputable, as welldeveloped infection tubes were found in the leaves. These will be described in the next section of the paper.

With regard to Cladosporium it may be mentioned in passing that this -fungus attacks the potato leaves chiefly after the plants have been earthed up. It is one of the common Fungi of the soil, and, when the soil is brought into contact with the leaves in the process of earthing up, the spores attack the lower leaves and the fungus gradually passes upwards, until the whole plant may be involved. Each spore and the hyphae formed from it kill a small area of the leaf, causing a yellow or brown spot. The veins are also very frequently attacked and become brown. The diseased areas gradually spread over the leaf, which becomes yellow, then dries up, and finally falls off.

Some experiments, both with seedlings and with plants from tubers, were also made during the summer in a greenhouse, but gave no results, without any doubt because it was not possible to prevent the temperature from rising far too high. On one occasion, with open windows and whitewashed roof, the temperature was $104^{\circ} \mathrm{F}$. Since the maximum growing point is $35^{\circ} \mathrm{C} .\left(95^{\circ} \mathrm{F}\right.$.), the optimum temperature for growth is of course lower. This fact, as well as the excessive drought, accounts for the fewness of the positive results obtained in the summer of I 9 I I after artificial infection.

\section{Examination of the artificially infected Plants.}

I. I9I0 Material. Few sections were cut through the material infected by puncture, because one of the chief objects in the experiments was to determine whether the infection took place through the uninjured epidermis, and this of course could not be seen when the leaf had been pierced artificially.

As in the case of naturally infected plants, no infection was seen to take place through either the water stomata or the ordinary stomata, though diseased leaf edges were specially examined. The fact that the 
withering of the leaves often begins at the apex or round the edges, and that the veins are the parts chiefly affected, seems to be explained by the fact (already pointed out, p. I44) that the water excreted at night round the edges of the leaves at the ends of the veins serves as a medium for the Bacteria, which thus obtain the large amount of moisture necessary for their growth. On the lower surface of the leaves the angle between the projecting vein and the lamina is also a common point of infection, doubtless because it affords shelter for the parasite (cf. Fig. II).

The Seedling Plants. Only one case of really clear and unmistakable tubes was found in cutting sections of seedling potato leaves. This was in a hand section of a comparatively large vein (Fig. I7). But other sections showed Bacteria in the cells of the affected parts of the leaves.

The Mature Potato Plants. These gave better results, though the experiments had to be stopped sooner than was desirable on account of the attack of Phytophthora. But definite tubes were obtained, and also early stages of infections were observed with less well defined tubes. In all cases, as in the spontaneously infected plants, the entrance of the Bacteria was through the epidermis and never by means of the stomata. Fig. 18 is an example of a tube which shows clearly the contained Bacteria, whereas in the naturally infected tubes distinct Bacteria were rarely if ever seen, perhaps because the tubes were older and emptied of their contents. This section also shows many Bacteria between the cells and outside the tube from which they may have escaped. It will be noticed that the tube is lying on the surface of the wall, on which are also Bacteria. Intercellular spaces are also to be seen with bacterial contents. Apparently the tubes are in an early stage of development, and the Bacteria have not yet penetrated into the interior of the cells, nor far into the tissues.

Fig. I 9 represents a case of infection without definite tubes, in which the bacteria make their way between the epidermal cells and the palisade cells and cross the intercellular spaces. As in the last figure the epidermal cells are injured, apparently by the entry of the Bacteria. In both cases Bacteria occur outside the section on the surface of the leaf. The Bacteria, both in spontaneously and in artificially infected leaves, cling so tenaciously to the outer surface of the leaf that they are not washed off by the various processes involved in making permanent microtome sections. It is therefore often possible to determine the exact spot where the infection was made.

In the case of the tomato seedlings no trace of tubes was found, but Bacteria were abundant inside the leaves, especially in the intercellular spaces and in the thin-walled cells of the larger veins. In both potato and tomato plants the epidermal cells were attacked very seriously. This is not usually the case in naturally infected plants. Perhaps the contact of the larger mass of material, often including some of the potato tuber underlying the Bacteria, may account for the greater injury. 
Several series of sections through the edges of leaves showed Bacteria entering between the cells and not by the stomata.

2. Material infected in I9II. The open-air experiments in I9II, in the earlier part of the season, gave more positive results, though on account of the hot, dry weather, these were fewer than had been hoped and expected. Of the plants infected on June 8 some leaves were cut and examined fresh on June 23 , i. e. fifteen days after infection. As before stated, it is difficult, except in the larger veins, to see tubes in fresh material on account of the presence of chlorophyll. It is quite possible, therefore, that tubes in the lamina may have been overlooked.

Three leaflets from a plant of 'White City' infected with the original organism were cut. The signs of disease were not far advanced, and the leaflets were only slightly brown. A very definite tube was seen in the first leaflet cut. From these leaflets a fresh culture of the organism was made, which resembled the original culture. On June 30 , that is, twenty-two days after infection, some more leaves were cut. A leaf of 'Up-to-Date' infected with the original organism contained good tubes in a vein which was cut. One large tube and some smaller ones were also seen in a leaf from a plant of 'White City' infected with the original organism (Fig. 20). A leaf of 'White City' infected with the thick gelatinous form also contained well-marked infection tubes and also many fungal hyphae. There is, however, no danger of confusing the two, as the fungal hyphae are thinwalled, have granular contents, branch, and are septate, whereas the bacterial tubes have thick refractive walls, and a narrow lumen with no contents, and seldom branch. There is, however, a doubt as to whether these tubes were really formed by the gelatinous organism or by the original Bacteria, as the infections were made on the upper side only, while the tubes were found only on the lower side. It is possible that some of the original Bacteria, known to form tubes, may have been transferred from one plant to another by the hands of the operator. To avoid this danger, subsequently only one kind of organism was used for infection on a given day, as there were no means of sterilizing one's hands properly in the field.

After this time, however, a severe drought set in, and the plants also became attacked by Cladosporium. No definite and unmistakable tubes were found in the leaves which were subsequently cut, except on July 8 , on another leaf of 'White City' infected on June 8 with the original organism. It is noteworthy that the tubes were confined to the upper side of the leaf, and that the upper side only had been infected. The leaf was so very slightly diseased that to the naked eye it seemed almost healthy.

No tubes were found in plants infected with the organism which was obtained from the plant in I9II, and which seemed identical with that obtained in I9I0. Bacteria were, however, found inside infected leaves. Leaves infected with the gelatinous organism, though showing no tubes, 
except in the doubtful case recorded above, not infrequently showed masses of Bacteria, in the condition of zoogloea, inside the tissues of the host and between the cells. It therefore seems as if this organism were also pathogenic to the potato.

In the case of plants infected with the original organism, Bacteria were sometimes found inside the host plant when no tubes were seen. This would seem to be a case of infection without definite tubes like those noticed the year before.

\section{Discussion of RESUlts.}

The experiments and observations recorded above lead to the conclusion that the disease under consideration is bacterial in nature. Various bacterial diseases of the potato and allied plants have already been described by different authors. A history and comparison of these diseases has lately been published by Pethybridge and $M$ urphy $^{1}$ in a paper describing a bacterial disease of potato shoots known as 'Black stalk-rot' or 'Blackleg', occurring in Ireland.

The bacterial diseases of the potato which have been most fully described are the one just referred to, and another worked out by Erwin Smith ${ }^{2}$ and called by him 'Potato Bacteriosis', which attacks not only the potato but other species of Solanum, especially the egg-plant (S. [Melongena] ovigerum) and tomato (Lycopersicum esculentum).

In potato 'Black stalk-rot', or 'Black-leg', as described by Massee, the symptoms are as follows: ${ }^{3}$ The leaves wilt and turn yellow, the lowest first. When the leaves droop the surface of the underground parts of the stem bearing such leaves is more or less covered with brown stains. Discoloration goes up the stem, which becomes black and decays. This disease was regarded by Carruthers, ${ }^{4}$ who does not, however, describe it in detail, to be due to Bacillus phytophthorus, which was first isolated and named by Appel. ${ }^{5}$ An organism was also isolated by Pethybridge and Murphy from potatoes affected with black stalk-rot, but it was not considered by them to be the same as (though closely allied to) that obtained by Appel. They therefore regard it as a new species, to which they give the name $B$. melanogenes.

The symptoms of 'Black stalk-rot' differ considerably from those of the disease at present under consideration, especially in the fact that the disease begins from below and spreads upwards, attacking chiefly the stems

1 Pethybridge and Murphy: v. p. I4I, supra.

${ }^{2}$ Erwin Smith: A Bacterial Disease of the Tomato, Egg-plant, and Irish Potato (Bacillus solanacearum, n. sp.). U. S. Department of Agriculture, Bull. No. 12, 1896.

${ }^{3}$ Massee: Diseases of Cultivated Plants and Trees, I9I0, p. 5 I4.

4 Carruthers: Journal of the Royal Agricultural Society of England, vol. 1xviii, 1907, p. 226.

5 Appel : see bibliography in the paper by Pethybridge and Murphy quoted above. 
and tubers, whereas in the disease here described the mischief not only begins in the leaves but is exclusively confined to them, so that, as far as can be determined at present, the stems and tubers are only indirectly affected by means of the destruction of the foliage. As is to be expected, the organisms isolated in each case also differ from one another. In the potato bacteriosis, described by Erwin Smith (1. c.), the parts chiefly attacked are also the stems and tubers, though the organs first attacked are the leaves, as in the disease now being described. But the two diseases differ essentially in the fact that, while in bacteriosis the vascular tissue is first attacked and the vessels blocked with the organism, the parenchyma being only affected subsequently, in the present disease the injury begins in the parenchyma, and spreads to the non-vascular tissues of the veins, while not apparently affecting directly the stems and tubers. For convenience in description the latter disease may shortly be called bacterial leaf disease to distinguish it from bacterial diseases chiefly affecting other organs, and also to distinguish it from leaf diseases, such as 'blight', due to Phytophthora or other Fungi. The mode of infection in the two diseases is also different. $B$. Solanacearum enters the vessels by means of the water stomata or through wounds, whereas in bacterial leaf disease the organism pierces the uninjured epidermis and passes first between the cell-walls.

Again, as might be expected, there are marked differences between the organisms causing the two diseases. The differences between the three organisms, viz. $B$. Solanacearum, causing bacteriosis, $B$. melanogenes, causing black stalk-rot, and the bacillus causing bacterial leaf disease, may most readily be seen and compared by means of the accompanying table ${ }^{1}$ (p. I $\left.5^{1}\right)$.

There seems to be no doubt, as a study of the table shows, that the organism causing bacterial leaf disease differs markedly from those already described, and that it must therefore be regarded as a new species, reluctant though one is to add another to the already long list. Since its most distinguishing characteristic is the power of forming tubes in the tissues of the host, like those already known in the Leguminosae, the most obvious specific name is one indicating this character. I propose, therefore, to call it B. Tubifex, n. sp.

The species, though parasitic on potato leaves, is also a saprophyte, as it grows strongly on various culture media as well as on the living leaf and tuber.

With regard to the mode of formation of the tubes a few words may here be said.

The organism evidently pierces the epidermis and passes between the cells by a process of fermentation in which the middle lamella is dissolved. That Bacteria possess this power has already been demonstrated by previous

1 Reference may also be made to the table given by Erwin Smith, in the paper above referred to, showing the differences between $B$. Solanacearum, $B$. tracheiphilus (the organism causing cucumber rot), and 'Kramer's Bacillus', causing a rot in potato tubers. 
workers. That $B$. Tubifex is able to cause fermentation is shown by its behaviour on culture media.

The tube itself is doubtless formed, as in the Leguminosae, by the union of the individual organisms into a zoogloea by means of the gelatinous envelope surrounding them. This envelope is only developed in subaerial cultures and not in liquid media. That the tube is not formed from the dissolved middle lamella of the cells of the host plant seems to be indicated by the fact that the tubes can be formed in, and cross over, large intercellular spaces in the mesophyll of the lamina.

The tube is therefore a kind of zoogloea, which penetrates the host by means of a ferment action which dissolves the middle lamella of the cells of the potato leaf. Apparently the Bacteria pass out of the tube into the cells of the host plant, leaving the matrix as a resistant, deeply staining tube, since all attempts to differentiate Bacteria by means of staining failed in the old tubes, though the same methods were used which were successfully employed by Miss Dawson in the case of the nodules of the Leguminosae.

Whether there is any relation between bacterial leaf-disease and leafcurl is uncertain. The constant symptoms of the former disease are a yellowing of the leaves accompanied by the formation of brown patches in the lamina and of a brown colour in the veins. These symptoms may or may not be accompanied by leaf-curl or leaf-roll. On the other hand, as stated above, leaf-curl may occur when no organism can be found in the subaerial shoots. Reinke and Berthold ${ }^{1}$ observed this fact, and came to the conclusion that curl is due to the presence of Verticillium albo-atrum, which may, however, be confined to the subterranean parts of the host and to the lower parts of the subaerial stem, though it may eventually grow upwards along the whole length of the shoot, and kill it by blocking up the vessels.

\section{Conclusions and Summary.}

Bacterial leaf-disease is due to Bacillus Tubifex, n. sp., which attacks the leaves of the potato plant by piercing the cuticle where this is thin enough for it to penetrate. The bacilli form a kind of zoogloea and dissolve the middle lamella of the host plant by means of a ferment, and so pass between, or in some cases across, the cells of the host plant by means of infection tubes like those present in the nodules of certain leguminous plants. Infection generally takes place near the edges of the leaves or along the veins either on the upper or under surface. The infection tubes grow at right angles to the surface of the lamina and sooner or later end in cells of the host plant, which become filled with Bacteria.

The disease appears to be more of theoretical than of practical importance, as in a fairly dry, hot summer the cuticle of the potato leaves would

${ }^{1}$ Reinke and Berthold: Zersetzung der Kartoffel. Die Kräuselkrankheit der Kartoffel, I879, p. 67 et seq. 
generally be too thick, and the temperature too high, to allow of the penetration of the organism. Any considerable attack would, however, be serious, as the leaves and shoots are completely destroyed and the formation of tubers consequently stopped. The disease has been most marked in plants grown in a cool greenhouse. The organism causing the disease is a bacillus differing in so many respects from those previously described as the cause of other potato diseases that it must be considered as a new species. On account of its power of forming infection tubes in the host plant it has been named Bacillus Tubifex, n. sp.

In culture it forms slimy masses of zoogloea on steamed potato tuber. These masses string out and stretch in films over large bubbles of gas, which are given off as the organism grows. The Bacteria have the power of causing fermentation. They are aerobic and anaerobic, and can live either as parasites or as saprophytes. Spore formation readily occurs.

My grateful thanks are due to Professor Biffen for allowing me to work in the School of Agriculture and at the University Farm, and for helping me with his advice during the course of my investigations.

\section{TABLE SHOWING THE CHARACTERISTICS OF DIFFERENT BACTERIA Pathogenic to Solanum tÚberosum.}

Bacillus Solanacearum (Smith).

I. Not sticky in the plant or on culture media, except slightly on agar.

2. Dirty white or yellowish white, then brownish and finally smoke-black. Browns vascular bundles.

3. Strictly aerobic. Will not grow in closed fermentation tubes with any sugar.

4. No acids with any sugar.

5. Intense alkali producer.

6. Slowly saponifies milk.

7. Decided but not particularly obnoxious smell-like some, but not all, rotting potatoes.

8. Grows readily at $37^{\circ} \mathrm{C}$.

9. Thermal death-point $52^{\circ} \mathrm{C}$.

10. Zoogloea in top layers of beef broth or peptone water as innumerable tiny whitish flecks, which are sometimes slightly inclined to unite into pellicle but diffuse through the liquid on shaking.

\section{Bacillus melanogenes}

(Pethybridge).

Exceedingly sticky and slimy in cultures, especially on potato tuber. It strings out from the needle.

White, except on sterile potato.

Slight growth occurs in stab cultures covered with agar.

Forms acid in glucose broth and in cane-sugar broth.

Coagulates milk within 48 hours. Gas bubbles formed. Colour of litmus goes.

Thermal death-point between $45^{\circ}$ and $50^{\circ} \mathrm{C}$.

Zoogloea not recorded.
Bacillus Tubifex, n. sp.

Like $B$. melanogenes.

White, then dirty white.

Not strictly aerobic. Will grow in presence of caustic soda and pyrogallin, and also in agar stab covered with agar.

Forms acid in cane-sugar and peptone in gelatine.

Coagulates milk in I or 2 days with formation of acid. Gas bubbles formed. Decolorizes neutral litmus.

Slight odour. On living potato smells ammoniacal.

Grows readily at $35^{\circ} \mathrm{C}$.

Thermal death-point between $45^{\circ}$ and $50^{\circ} \mathrm{C}$.

Like $B$. Solanacearum, but also forms films on the surface which break up and sink when the fluid is shaken. 


\section{Bacillus Solanacearum}

(Smith).

II. Growth on gelatine not leaflike.

12. Does not liquefy gelatine.

J3. No gas in potato or in media with various sugars.

14. No acid formed in potato or glucose solutions containing nitrogenous substances.

15. Goes through bundles into tuber, where cavities are formed.

16. No spores.

17. Sluggishly motile, active in young cultures.

18. Bacilli in short rods.

\section{Bacillus melanogenes}

(Pethybridge).

Liquefies gelatine fairly rapidly. Begins the second day in gelatine stab.

Slight formation of gas with sugar.

Forms acid.

In subaerial stems.

No spores.

Actively motile. Peritrichous flagellae.

Bacilli often in pairs or in threes or in long chains. Vary little in size. $\mathbf{I} \cdot \mathbf{3}$ to $1.8 \times 0.9 \mu$. Chains up to 20 or $70 \mu$. 5 to 10 peritrichous flagella.

In vascular tissue of the stem of the potato plant.

host plant. At first only in the vascular tissues, but later in parenchyma.

20. Infection through wounds caused by insects, \&c.

21. Injury caused chiefly by the blocking up of the vessels. Almost entirely confined to stems and tubers.

22. Causes wilting and browning of foliage and stems.

25.

26.

27.
Causes blackening of stems, withering of leaves, and rotting of tubers.

On gelatine plates forms minute white dots. Liquefaction after the second day. in 48 hours as in gelatine. Surface covered with greyish white growth, somewhat crenated along the margin.

Not vigorous in beef extract peptone.

In cane-sugar broth gas and acid produced.

Active growth in potato juice.
On agar whitedotsare formed
Bacillus Tubifex, n. sp.

Forms circular colonies on gelatine plates.

Liquefies gelatine rather slowly.

Forms large bubbles of gas on potato and in cane-sugar and peptone in gelatine.

Forms acid in cane-sugar and peptone in gelatine.

Not found in tuber nor in stems, but only in leaves, especially in the veins but not in the vessels.

Spores formed readily and plentifully in a few days on potato tuber.

Actively motile in liquid media.

Bacilli in short rods and long filaments of all lengths according to conditions of growth, nature of medium, age of culture,\&c. Flagellate. Average size $3.7 \times \mathbf{I} .23 \mu$, minimum $2.4 \times 0.8 \mu$, maximum $5 \times 1.7 \mu$.

Bacilli in and between the cells of the parenchyma and phloem. Seldom in the vessels and only in later stages.

Infection through uninjured epidermis by means of infection tubes, as in the nodules of certain leguminous plants.

Injury caused by disorganization of tissues due to passage of infection tube, and by lesions in cells filled with Bacteria. Also indirectly by the using up of the products of metabolism. Almost confined to leaves.

Causes withering and drying of leaves from outside inwards. Often accompanied by 'curl', but not always.

White dots on second day on gelatine plates and along line of stab. Liquefies gelatine.

On agar plates dots as on gelatine. In stab cultures forms wavy films along the line of stab.

Rapid growth in 'Lemco'.

In cane-sugar-peptone gelatine gas and acid produced. Active growth in liquid extract of potato tuber. 


\section{Bacillus Solanacearum}

(Smith).

28.

29.

3 . -

\section{Bacillus melanogenes}

(Pethybridge).

Produces enzyme capable of dissolving the middle lamella of cells.

On sterile potato at $25^{\circ} \mathrm{C}$. yellow slimy growth is formed in 2 days. After 6 days becomes brown.

On living potato. Slight brown colour, later black. Middle lamella dissolved. Moisture needed.
Bacillus Tubifex, n. sp.

Produces enzyme capable of dissolving the middle lamella of cells.

On sterile potato at $20^{\circ} \mathrm{C}$. a dirty white slimy growth is formed, raised up into bubbles.

As $B$. melanogenes. Smells strongly ammoniacal on living potato. Goes brown.

\title{
School of Agriculture, CAMBRIDGE. \\ October, I9II.
}

\section{EXPLANATION OF FIGURES IN PLATES XV AND XVI.}

\author{
Illustrating Miss Dale's paper on a Bacterial Disease of Potato Leaves.
}

\section{PLATE XV.}

Fig. I. Surface view of the epidermis of a potato leaf, showing the bacterial infection tubes entering the tissues of the host through the cuticle and not through the stomata. The tubes are coloured red in all the figures. 4 oc. $2 \mathrm{~mm}$. obj. (oil immersion).

Fig. 2. Surface view of older stage to show the lumen. Note that the cell-walls on each side of both tubes are stained pink because they have been chemically altered by the parasite. $4 \mathrm{oc}$. $2 \mathrm{~mm}$. obj.

Fig. 3. Another surface view of older stage with the end of the tube more thickened. 4 oc. $2 \mathrm{~mm}$. obj.

Fig. 4. Transverse section of an epidermal cell and of adjacent cells, showing two tubes which are markedly thickened at the surface of the leaf. Note the prolongations above the surface in the left-hand tube and the lumen, and the dilatation where the right-hand tube pierces the cell-walls of the host. 4 oc. $2 \mathrm{~mm}$. obj.

Fig. 5. A young complete tube with a single narrow projection beyond the epidermis. The tube widens gradually with very irregular contours and shows several constrictions. Towards its inner end it becomes narrower, and there are traces of granular contents in the lumen. $40 c .2 \mathrm{~mm}$. obj.

Fig. 6. A short piece of a tube, shown where it crosses three cell-walls. The swellings at the points where the walls of the host cells are pierced is very marked. $40 c .2 \mathrm{~mm} . o b j$.

Fig. 7. A portion of a tube to show the behaviour in an intercellular space. The surrounding cells are more or less diseased and contain some Bacteria. 4 oc. $2 \mathrm{~mm} .0 \mathrm{oj}$.

Fig. 8. Two tubes in a later stage of the disease. These tubes anastomose and branch, ending in the phloem of a small vein. A few Bacteria are to be seen on the surface of the leaf near the outer ends of the tubes. One of the cells of the host, immediately below the epidermis, is filled with Bacteria and its chloroplasts are degenerating. The intercellular course of the tubes is very clearly shown in this section. $4 o c . D o b j$.

Fig. 9. One tube is here seen branching and passing between the cells of the host into a small vein where some of the cells and vessels contain Bacteria. 4 oc. $D$ obj.

Fig. 10. This shows an unusually large number of tubes, in close proximity, in the neighbourhood of $a_{8}$ large vein. The tubes are seen at the surface, where each ends in several points. They have a more or less nearly straight course and are unbranched. Numerous cells containing Bacteria are also represented. Other examples, showing equally numerous tubes, were met with in examining series of microtome sections. $4 o c . D o b j$. 


\section{PLATE XVI.}

Fig. II. A long tube is here seen from the point of entrance in the angle between the vein and the lamina of a leaf to its ending in the phloem of the vascular bundle. On each side of the tube, along its tortuous course, are diseased cells containing Bacteria, and a few Bacteria may be seen lying outside the leaf round the mouth of the tube. Incidentally this section shows how the tubes, so to speak, avoid the stomata, one of which lies close to the outer end of the tube. 2 oc. $D$ obj.

Fig. 12. The section is of a considerably diseased leaf with several branching and anastomosing tubes passing from the exterior into a small vein. The Bacteria have only attacked the cells and not the vessels. Many cells of the parenchyma are filled with Bacteria. $4 o c . D o b j$.

Fig. I3. This shows a few cells filled with Bacteria and containing the endings of the tubes. One tube is seen in transverse section in an intercellular space. 4 oc. $3 \mathrm{~mm}$. obj.

Fig. 14. Section of potato tuber, sterilized by steaming, and infected with Bacteria. The Bacteria are very numerous between the cells, which, after being steamed, are only loosely attached to one another. There are only a few Bacteria inside the cells, whose starchy contents are apparently only slightly attacked. 2 oc. $\frac{1}{2}$ inch obj.

Fig. I5. Section of living potato tuber infected with Bacteria. Rotting was only beginning and the tissues were still firm. As in the dead tuber, the Bacteria are most abundant between the cells, whose walls have here been separated by the organism, which has destroyed the middle lamella and chemically changed the cell-walls so that they stain red. The organism has formed spores in the intercellular spaces. The large red spheres are starch grains, which have not been attacked by the Bacteria. 2 oc. $\frac{1}{12} o b j$.

Fig. 16. Formation of spores in the bacilli. $a \mathrm{I}$. Ordinary vegetative bacilli. $a$ 2. Very long rod. $b$. Rods enlarging to form spores. $c$. Contents contracting from the wall. A faintly staining halo of zoogloea surrounds these rods. $d$. The contents breaking up into short lengths. $e$. Ripe spores showing deep apical staining. $f$. Two spores in a rod. This is very frequent. $g$. Rod with two spores, only one of which has matured. $h$. Portion of a zoogloea. $40 c_{2} 2 \mathrm{~mm}$.

Fig. I 7. Section of a leaf of a seedling potato plant, artificially infected with Bacteria from a pure culture. Two tubes are seen entering at the lower surface and growing towards the vascular tissues. The plant was grown and infected in a cool greenhouse. 2 oc. $D$ obj.

Fig. I8. An artificially infected leaf of a mature plant from a tuber, grown and infected in the open. Many of the Bacteria used for infection are still clinging to the upper epidermis. A single tube is seen passing along a palisade cell. Bacteria are also seen in the intercellular spaces and inside the epidermal cells. 4 oc. $2 \mathrm{~mm}$.

Fig. I9. Represents a case of infection without definite tubes. Numerous Bacteria may be seen passing between the cells and also inside an epidermal cell. 4 oc. $2 \mathrm{~mm}$.

Fig. 20. Several tubes from a leaf of 'White City' variety of potato, artificially infected on the University Farm. The tubes are typical and exactly like those found in naturally infected plants. The swellings where the cell-walls of the host plant are pierced are very marked. 4 oc. $2 \mathrm{~mm}$.

N.B. - It should be noted that in all cases the tubes run across the veins and lamina, and never in any case parallel to the surface of the leaf. 
Annals of Botany,

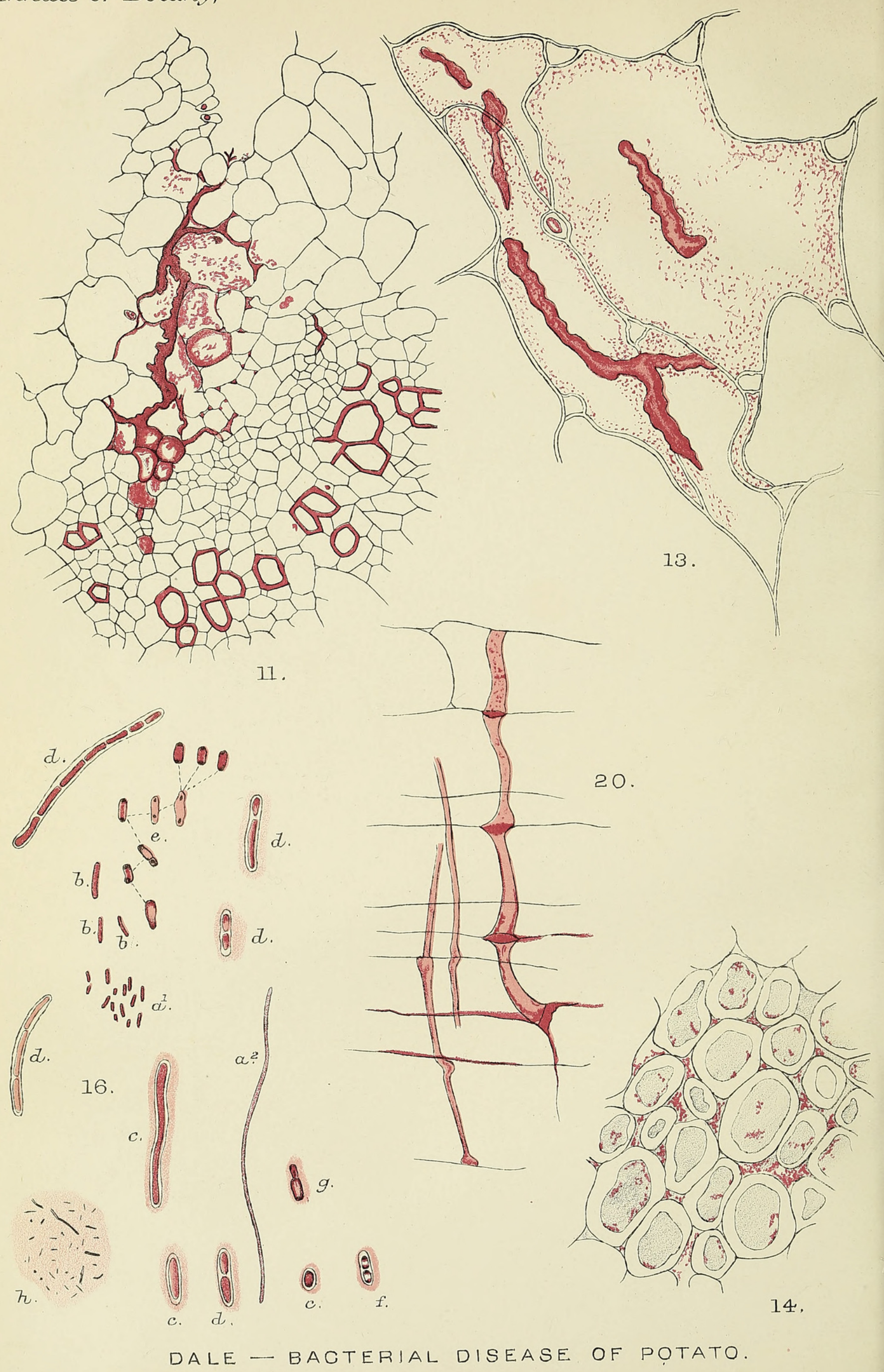




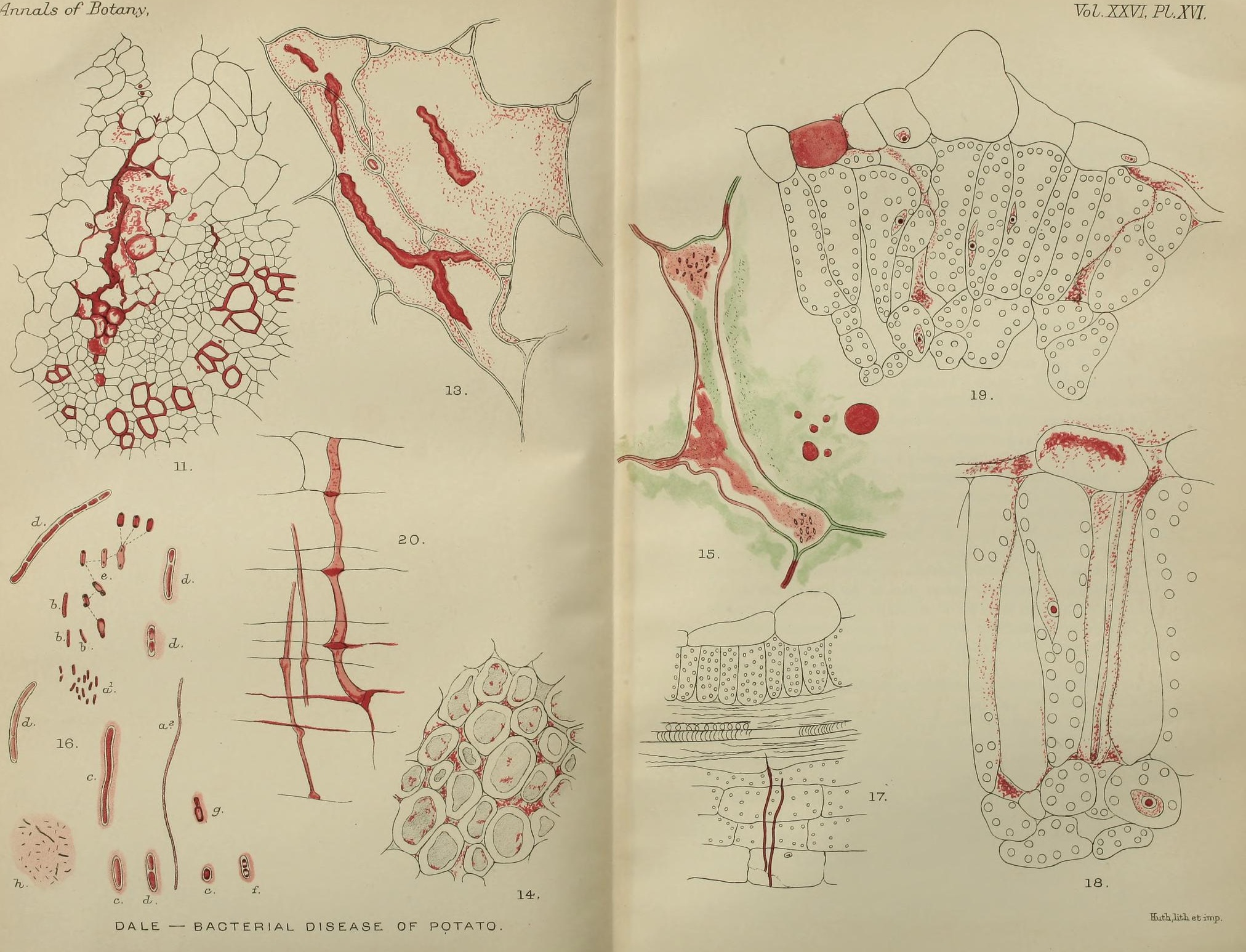




\section{$2 \mathrm{BHL}$ Biodiversity Heritage Library}

Dale, Elizabeth. 1912. "A bacterial disease of potato leaves." Annals of botany 26, 133-154. https://doi.org/10.1093/oxfordjournals.aob.a089381.

View This Item Online: https://www.biodiversitylibrary.org/item/236773

DOI: https://doi.org/10.1093/oxfordjournals.aob.a089381

Permalink: https://www.biodiversitylibrary.org/partpdf/319898

\section{Holding Institution}

Smithsonian Libraries

\section{Sponsored by}

Biodiversity Heritage Library

\section{Copyright \& Reuse}

Copyright Status: Not in copyright. The BHL knows of no copyright restrictions on this item.

This document was created from content at the Biodiversity Heritage Library, the world's largest open access digital library for biodiversity literature and archives. Visit BHL at https://www.biodiversitylibrary.org. 